\title{
Impact of different levels of organic and inorganic fertilizers on growth, yield and quality of preseasonal sugarcane ratoon in Inceptisols
}

\author{
N. B. Ghube' ${ }^{1}$ A. D. Kadlag ${ }^{2}$ and B. M. Kamble ${ }^{3 *}$ \\ ${ }^{\mathbf{1}}$ Department of Soil Science and Agricultural Chemistry, College of Agriculture, Naigaon (Bz)-431709, \\ (Maharashtra), INDIA \\ ${ }^{2}$ Department of Soil Science and Agricultural Chemistry, Mahatma Phule Krishi Vidyapeeth, Rahuri- 413722 \\ (Maharashtra), INDIA \\ ${ }^{3}$ Agricultural Research Station, Kasabe Digraj, Sangli- 416305 (Maharashtra), INDIA \\ *Corresponding author. E-mail:bmkamble2007@rediffmail.com \\ Received: October 14, 2016; Revised received: January 30, 2017; Accepted: April 23, 2017
}

\begin{abstract}
A field experiment was conducted at soil test crop response (STCR) correlation project farm of Mahatma Phule Krishi Vidyapeeth, Rahuri Maharashtra.The result showed that individual application of nitrogen (N), phosphorus $(P)$, potassium $(K)$ or organic nutrient sources (Farm yard manure) recorded less value of preseasonal sugarcane ratoon but the integration of both the sources showed significantly improved all the growth, yield and quality parameters of preseasonal sugarcane ratoon. The maximum number of internodes were ranged between 21-30 with mean of 25.42, number of leaves 6-10 with mean of 7.21, length of internodes $12.50-16.80 \mathrm{~cm}$ with mean of $14.41 \mathrm{~cm}$, girth of internodes $11.30-13.10 \mathrm{~cm}$ with mean of $12.15 \mathrm{~cm}$ and height of millable cane 335-385 with mean of 351.75 $\mathrm{cm}$, respectively were found higher with application of residual effect of $30 \mathrm{t} \mathrm{ha}^{-1}$ farm yard manure (FYM). However, the quality traits viz., brix ranged from 18.70 to 22.80 with mean of 19.87 , pol per cent ranged from 15.81 to 18.41 per cent with mean of 17.53 per cent and commercial cane sugar (CCS) per cent from 9.39 to 12.09 per cent with mean of 10.76 per cent. The CCS yield was ranged between 9.58-16.30 $\mathrm{MT} \mathrm{ha}^{-1}$ with mean value of 14.13 MT $\mathrm{ha}^{-1}$ were enhanced considerably with residual 15 and $30 \mathrm{t} \mathrm{FYM} \mathrm{ha}^{-1}$ blocks over without FYM. The application of organic and inorganic fertilizers will not only enhance the growth, yield and quality of preseasonal sugarcane ratoon but also conserve agro-ecosystem for sustainable crop production.
\end{abstract}

Keywords: Growth, Inorganic and organic fertilizer, Preseasonal sugarcane ratoon, Quality and Yield

\section{INTRODUCTION}

Sugarcane is an economically important crop next only to cotton. It provides rich source of sucrose, alcohol and organic matter waste which is utilized as fertilizer. Sugarcane was cultivated vegetatively as noble canes until the end of $20^{\text {th }}$ century. Sugarcane occupies a pivotal position in the agriculture economy of India. As an instrument of agrarian reform and economic emancipation, sugarcane is second to none. This is so because it a labour intensive crop and provides livelihood to millions through an organised industry that it carries with it in the rural India. Sugarcane cultivated on an area of 50.67 lakh hectares in 2014-15 with a production of 362.33 million tonnes with an average productivity of $71.51 \mathrm{t} \mathrm{ha}^{-1}$ in India, through, there is a wide variations with productivity across different regions. Maharashtra is one of the leading producing state in the country having area about 10.30 lakh hectares with cane production 82.23 million tonnes with an average cane production of $73.20 \mathrm{t} \mathrm{ha}^{-1}$ during the year 2014-15 and recovery of $11.91 \%$ (Anonymous, 2016).
Sugarcane is a long duration and exhaustive crop, which produce large quantum biomasss removes considerable amount of nutrients from soil for its normal growth and development. It has been measured that sugarcane of $100 \mathrm{t}$ that produced from 1 ha land removes 140, 34 and $332 \mathrm{~kg} \mathrm{NPK} \mathrm{ha}{ }^{-1}$, respectively, from soil (Bokhtiar et al., 2001). Several researchers have demonstrated the beneficial effect of combined use of chemical and organic fertilizers to mitigate the deficiency of many secondary and micro nutrients in field that continuously received only N,P and K fertilizers for a few years, without any micronutrients or organic fertilizer. Bokhtiar et al. (2015) reported that the combined application of enriched pressmud or raw pressmud with chemical fertilizers improved the cane yield and the effect was more pronounced at higher fertilizer level (100\% RDF). Ramalakshmi et al. (2011) found that the integrated use of organic manures and inorganic fertilizers produced higher and sustainable cane yields and maintained the soil fertility. Ratoon keeping in sugarcane is economic for the farming community of which production cost is lower than plant crop by $25.35 \%$ along with saving of seed 
material. A ratoon crop mature prior to plant crop ensuring early supply of cane mills under similar condition sugarcane ratoon have a supplementary advantage of better juice quality and sugar recovery more than plant crop of same variety (Eid et al.,2016). The soil test crop response (STCR) approach for targeted yield is unique in indicating both the soil test base fertilizer dose and the level of yield that can be achieved with good management practices. In order to sustain the yield and to reduce the cost of fertilizer and in turn cost of cultivation, Vajantha et al.(2014) noticed that the application of fertilizers based on STCR equation for target yield of $120 \mathrm{t} \mathrm{ha}^{-1}$ recorded highest cane yield $\left(121.5,117.8,114.2 \mathrm{t} \mathrm{ha}^{-1}\right.$ in plant crop I, plant crop II, ratoon respectively). However, the STCR equation for targeted yield of $100 \mathrm{t} \mathrm{ha}^{-1}$ in sugarcane could be achieved without any negative deviation in Chittoor district soils. Sakarvadia et al. (2012) found that the yield targeting approach is effective also in soil fertility build up. The fertilizer application practices based on targeted yield approach indicated the possibility of enhancing production potentials of sugarcane in major sugarcane growing pockets of Maharashtra, viz; Ahmednagar, Pune, Solapur, Satara, Sangli. Targeted yield equations in the country are available pertaining to respective states and varieties. In Maharashtra the yield target equation for preseasonal sugarcane was developed during 1996 for var Co 86032 on Vertisols without considering the contribu- tion of FYM. This equation was not found applicable to other varieties. Further the major soils in western Maharashtra are of medium depth and come under the order Inceptisol. Hence in this context, an experiment was conducted to study the application different of levels of organic and inorganic fertilizes on medium deep soil (Inceptisols) for growth, yield and quality of sugarcane ratoon $\mathrm{C} 0-94012$.

\section{MATERIALS AND METHODS}

The standard field experiment was conducted on preseasonal sugarcane (ratoon) at Mahatma Phule Krishi Vidyapeeth, Rahuri, Maharashtra, India using a fertility gradient approach. The experimental location was between $19^{\circ} 48^{\prime} \mathrm{N}$ and $19^{\circ} 57^{\prime} \mathrm{N}$ latitude and $74^{\circ}$ $19^{\prime}$ E longitude. In the gradient experiment, operational range of variation in soil fertility was created deliberately. For this purpose, the experimental field was divided into three equal strips, the first strip received no fertilizer $\left(\mathrm{N}_{0} \mathrm{P}_{0} \mathrm{~K}_{0}\right)$, the second and third strips received one $\left(\mathrm{N}_{1} \mathrm{P}_{1} \mathrm{~K}_{1}\right)$ and two $\left(\mathrm{N}_{2} \mathrm{P}_{2} \mathrm{~K}_{2}\right)$ times the standard dose of $\mathrm{N}, \mathrm{P}_{2} \mathrm{O}_{5}$ and $\mathrm{K}_{2} \mathrm{O}$ respectively and a gradient crop of fodder maize was grown. The variation in fertility gradient in different fertility gradient were observed from the soil test values in three fertility gradients. These fertility gradients were used for derivation of fertilizer prescription equation for plant preseasonal sugarcane ratoon. After harvest of plant preseasonal sugarcane the similar fertility gradient

Table 1. Effect of fertilization on growth parameter of pre-seasonal sugarcane ratoon in without FYM block.

\begin{tabular}{|c|c|c|c|c|c|c|}
\hline \multirow[b]{2}{*}{$\begin{array}{l}\text { Tr. } \\
\text { No. }\end{array}$} & \multirow[b]{2}{*}{ Treatment } & \multicolumn{5}{|c|}{ Fo $\left(0 \mathrm{t} \mathrm{ha}^{-1}\right)$} \\
\hline & & $\begin{array}{l}\text { Number of } \\
\text { internodes }\end{array}$ & $\begin{array}{c}\text { Number of } \\
\text { Leaves }\end{array}$ & $\begin{array}{l}\text { Length of inter- } \\
\text { nodes }(\mathrm{cm})\end{array}$ & $\begin{array}{l}\text { Girth of inter- } \\
\text { nodes (cm) }\end{array}$ & $\begin{array}{c}\text { Height of milla- } \\
\text { ble cane }(\mathrm{cm})\end{array}$ \\
\hline 1 & $\mathrm{~N}_{0} \mathrm{P}_{115} \mathrm{~K}_{115}$ & 20 & 9 & 10.50 & 8.90 & 320 \\
\hline 2 & $\mathrm{~N}_{150} \mathrm{P}_{65} \mathrm{~K}_{65}$ & 23 & 8 & 11.00 & 8.20 & 331 \\
\hline 3 & $\mathrm{~N}_{150} \mathrm{P}_{65} \mathrm{~K}_{115}$ & 22 & 8 & 12.00 & 9.00 & 310 \\
\hline 4 & $\mathrm{~N}_{150} \mathrm{P}_{115} \mathrm{~K}_{65}$ & 21 & 7 & 12.15 & 7.90 & 300 \\
\hline 5 & $\mathrm{~N}_{150} \mathrm{P}_{115} \mathrm{~K}_{115}$ & 22 & 6 & 11.20 & 7.80 & 335 \\
\hline 6 & $\mathrm{~N}_{250} \mathrm{P}_{0} \mathrm{~K}_{115}$ & 20 & 7 & 11.50 & 8.80 & 330 \\
\hline 7 & $\mathrm{~N}_{250} \mathrm{P}_{65} \mathrm{~K}_{65}$ & 25 & 7 & 12.50 & 8.80 & 310 \\
\hline 8 & $\mathrm{~N}_{250} \mathrm{P}_{65} \mathrm{~K}_{115}$ & 25 & 6 & 11.50 & 8.80 & 325 \\
\hline 9 & $\mathrm{~N}_{250} \mathrm{P}_{115} \mathrm{~K}_{65}$ & 23 & 6 & 11.50 & 9.80 & 315 \\
\hline 10 & $\mathrm{~N}_{250} \mathrm{P}_{115} \mathrm{~K}_{0}$ & 25 & 7 & 12.40 & 8.80 & 335 \\
\hline 11 & $\mathrm{~N}_{250} \mathrm{P}_{115} \mathrm{~K}_{115}$ & 23 & 7 & 11.20 & 8.80 & 340 \\
\hline 12 & $\mathrm{~N}_{250} \mathrm{P}_{115} \mathrm{~K}_{165}$ & 22 & 7 & 12.00 & 7.98 & 318 \\
\hline 13 & $\mathrm{~N}_{250} \mathrm{P}_{165} \mathrm{~K}_{115}$ & 21 & 6 & 11.66 & 8.00 & 320 \\
\hline 14 & $\mathrm{~N}_{250} \mathrm{P}_{165} \mathrm{~K}_{165}$ & 20 & 6 & 10.83 & 8.65 & 322 \\
\hline 15 & $\mathrm{~N}_{350} \mathrm{P}_{65} \mathrm{~K}_{65}$ & 25 & 7 & 12.00 & 9.80 & 315 \\
\hline 16 & $\mathrm{~N}_{350} \mathrm{P}_{115} \mathrm{~K}_{65}$ & 23 & 6 & 12.60 & 10.85 & 325 \\
\hline 17 & $\mathrm{~N}_{350} \mathrm{P}_{115} \mathrm{~K}_{115}$ & 22 & 7 & 11.50 & 10.00 & 318 \\
\hline 18 & $\mathrm{~N}_{350} \mathrm{P}_{115} \mathrm{~K}_{165}$ & 22 & 7 & 13.00 & 10.70 & 330 \\
\hline 19 & $\mathrm{~N}_{350} \mathrm{P}_{165} \mathrm{~K}_{65}$ & 26 & 7 & 13.65 & 10.80 & 335 \\
\hline 20 & $\mathrm{~N}_{350} \mathrm{P}_{165} \mathrm{~K}_{115}$ & 25 & 6 & 13.33 & 10.80 & 310 \\
\hline 21 & $\mathrm{~N}_{350} \mathrm{P}_{165} \mathrm{~K}_{165}$ & 25 & 7 & 15.00 & 10.80 & 365 \\
\hline 22 & $\mathrm{~N}_{0} \mathrm{P}_{0} \mathrm{~K}_{0}$ & 19 & 6 & 9.00 & 8.90 & 290 \\
\hline 23 & $\mathrm{~N}_{0} \mathrm{P}_{0} \mathrm{~K}_{0}$ & 18 & 5 & 8.95 & 8.10 & 273 \\
\hline 24 & $\mathrm{~N}_{0} \mathrm{P}_{0} \mathrm{~K}_{0}$ & 19 & 7 & 9.20 & 7.90 & 265 \\
\hline Ave & of treated plots & 22.33 & 6.75 & 11.67 & 9.12 & 318 \\
\hline Ave & e of control plots & 18.66 & 6 & 9.05 & 8.30 & 276 \\
\hline
\end{tabular}


N. B. Ghube et al. / J. Appl. \& Nat. Sci. 9 (2): 812 - 820 (2017)

Table 2. Effect of fertilization on growth parameter of pre-seasonal sugarcane ratoon in $15 \mathrm{t} \mathrm{FYM} \mathrm{ha}^{-1}$ block.

\begin{tabular}{|c|c|c|c|c|c|c|}
\hline \multirow[b]{2}{*}{ Tr. No. } & \multirow[b]{2}{*}{ Treatment } & \multicolumn{5}{|c|}{ F1 $\left(15 \mathrm{t} \mathrm{ha}^{-1}\right)$} \\
\hline & & $\begin{array}{l}\text { Number of } \\
\text { internodes }\end{array}$ & $\begin{array}{c}\text { Number of } \\
\text { leaves }\end{array}$ & $\begin{array}{c}\text { Length of inter- } \\
\text { nodes }(\mathrm{cm})\end{array}$ & $\begin{array}{c}\text { Girth of inter- } \\
\text { nodes }(\mathrm{cm})\end{array}$ & $\begin{array}{c}\text { Height of milla- } \\
\text { ble cane (cm) }\end{array}$ \\
\hline 1 & $\mathrm{~N}_{0} \mathrm{P}_{115} \mathrm{~K}_{115}$ & 22 & 9 & 11.50 & 10.30 & 331 \\
\hline 2 & $\mathrm{~N}_{150} \mathrm{P}_{65} \mathrm{~K}_{65}$ & 20 & 8 & 12.00 & 10.00 & 341 \\
\hline 3 & $\mathrm{~N}_{150} \mathrm{P}_{65} \mathrm{~K}_{115}$ & 23 & 8 & 13.00 & 9.80 & 320 \\
\hline 4 & $\mathrm{~N}_{150} \mathrm{P}_{115} \mathrm{~K}_{65}$ & 24 & 7 & 12.50 & 9.20 & 321 \\
\hline 5 & $\mathrm{~N}_{150} \mathrm{P}_{115} \mathrm{~K}_{115}$ & 22 & 6 & 12.00 & 10.30 & 335 \\
\hline 6 & $\mathrm{~N}_{250} \mathrm{P}_{0} \mathrm{~K}_{115}$ & 23 & 7 & 13.15 & 11.60 & 345 \\
\hline 7 & $\mathrm{~N}_{250} \mathrm{P}_{65} \mathrm{~K}_{65}$ & 21 & 7 & 12.90 & 11.70 & 330 \\
\hline 8 & $\mathrm{~N}_{250} \mathrm{P}_{65} \mathrm{~K}_{115}$ & 25 & 6 & 11.38 & 10.30 & 337 \\
\hline 9 & $\mathrm{~N}_{250} \mathrm{P}_{115} \mathrm{~K}_{65}$ & 26 & 6 & 12.48 & 10.85 & 325 \\
\hline 10 & $\mathrm{~N}_{250} \mathrm{P}_{115} \mathrm{~K}_{0}$ & 26 & 7 & 11.70 & 10.70 & 340 \\
\hline 11 & $\mathrm{~N}_{250} \mathrm{P}_{115} \mathrm{~K}_{115}$ & 27 & 6 & 12.50 & 10.90 & 360 \\
\hline 12 & $\mathrm{~N}_{250} \mathrm{P}_{115} \mathrm{~K}_{165}$ & 22 & 6 & 12.60 & 10.65 & 330 \\
\hline 13 & $\mathrm{~N}_{250} \mathrm{P}_{165} \mathrm{~K}_{115}$ & 23 & 6 & 12.70 & 10.80 & 355 \\
\hline 14 & $\mathrm{~N}_{250} \mathrm{P}_{165} \mathrm{~K}_{165}$ & 24 & 6 & 12.50 & 11.80 & 345 \\
\hline 15 & $\mathrm{~N}_{350} \mathrm{P}_{65} \mathrm{~K}_{65}$ & 24 & 6 & 13.00 & 11.80 & 330 \\
\hline 16 & $\mathrm{~N}_{350} \mathrm{P}_{115} \mathrm{~K}_{65}$ & 23 & 7 & 13.80 & 12.10 & 340 \\
\hline 17 & $\mathrm{~N}_{350} \mathrm{P}_{115} \mathrm{~K}_{115}$ & 26 & 6 & 13.40 & 12.35 & 328 \\
\hline 18 & $\mathrm{~N}_{350} \mathrm{P}_{115} \mathrm{~K}_{165}$ & 25 & 6 & 13.50 & 11.80 & 342 \\
\hline 19 & $\mathrm{~N}_{350} \mathrm{P}_{165} \mathrm{~K}_{65}$ & 26 & 7 & 13.60 & 11.20 & 355 \\
\hline 20 & $\mathrm{~N}_{350} \mathrm{P}_{165} \mathrm{~K}_{115}$ & 27 & 7 & 13.98 & 11.35 & 360 \\
\hline 21 & $\mathrm{~N}_{350} \mathrm{P}_{165} \mathrm{~K}_{165}$ & 27 & 7 & 13.85 & 11.55 & 365 \\
\hline 22 & $\mathrm{~N}_{0} \mathrm{P}_{0} \mathrm{~K}_{0}$ & 24 & 6 & 11.50 & 9.60 & 310 \\
\hline 23 & $\mathrm{~N}_{0} \mathrm{P}_{0} \mathrm{~K}_{0}$ & 22 & 7 & 10.00 & 8.70 & 301 \\
\hline 24 & $\mathrm{~N}_{0} \mathrm{P}_{0} \mathrm{~K}_{0}$ & 21 & 5 & 10.50 & 8.50 & 320 \\
\hline \multicolumn{2}{|c|}{ Average of treated plots } & 23.88 & 6.63 & 12.50 & 10.74 & 336 \\
\hline \multicolumn{2}{|c|}{ Average of control plots } & 22.33 & 6 & 10.66 & 8.93 & 310 \\
\hline
\end{tabular}

(strip) were used for conduct of soil test crop response correlation studies to develop fertilizer prescription equation for preseasonal ratoon sugarcane. Variation in fertility gradient was assessed treatment wise with strip by testing soil available NPK at harvest of plant preseasonal sugarcane. These soil test value assessed gradients (strips) are used as fertility gradient for conduct of preseasonal ratoon sugarcane. In fertility gradient experiment, the soil analysis data after harvest of plant preseasonal sugarcane showed that fertility gradients were created in the $F_{0}, F_{1}$ and $F_{2}$ strips. The yield of plant in preseasonal sugarcane and soil fertility, the data on soil test values for available N,P and K at harvest of plant preseasonal sugarcane are used as fertility gradient for preseasonal ratoon sugarcane. After confirming the establishment of fertility gradients in the experimental field, in the second phase of the field experiment, three FYM blocks were created across the fertility gradient by applying three levels $\left(F_{1} 0, F_{2} 15\right.$ and $\mathrm{F}_{3} 30 \mathrm{t} \mathrm{ha}^{-1}$ ) of FYM. Three FYM blocks were created across the fertility gradient. The experiment was laid out in a fractional factorial design comprising twenty four equal plots with varying $21 \mathrm{~N}, \mathrm{P}_{2} \mathrm{O}_{5}$ and $\mathrm{K}_{2} \mathrm{O}$ treatments along with 3 control treatments on randomized basis. The different combinations of various levels of $\mathrm{N}\left(150,250\right.$ and $\left.350 \mathrm{~kg} \mathrm{ha}^{-1}\right), \mathrm{P}_{2} \mathrm{O}_{5}(65$, 115 and $\left.165 \mathrm{~kg} \mathrm{ha}^{-1}\right)$ and $\mathrm{K}_{2} \mathrm{O}(65,115$ and $165 \mathrm{~kg}$ ha $\left.{ }^{1}\right)$ were randomly distributed in $F_{0}, F_{1}$ and $F_{2}$ strip. The twenty one treatments consisted as $\mathrm{N}_{0}: \mathrm{P}_{115}: \mathrm{K}_{115}$, $\mathrm{N}_{150}: \mathrm{P}_{65}: \mathrm{K}_{65}, \mathrm{~N}_{150}: \mathrm{P}_{65}: \mathrm{K}_{115}, \mathrm{~N}_{150}: \mathrm{P}_{115}: \mathrm{K}_{65}, \mathrm{~N}_{150}$ :
$\mathrm{P}_{115}: \mathrm{K}_{115}, \mathrm{~N}_{250}: \mathrm{P}_{0}: \mathrm{K}_{115}, \mathrm{~N}_{250}: \mathrm{P}_{65}: \mathrm{K}_{65}, \mathrm{~N}_{250}: \mathrm{P}_{65}$ : $\mathrm{K}_{115}, \mathrm{~N}_{250}: \mathrm{P}_{115}: \mathrm{K}_{65}, \mathrm{~N}_{250}: \mathrm{P}_{115}: \mathrm{K}_{0}, \mathrm{~N}_{250}: \mathrm{P}_{115}: \mathrm{K}_{115}$, $\mathrm{N}_{250}: \mathrm{P}_{115}: \mathrm{K}_{165}, \mathrm{~N}_{250}: \mathrm{P}_{165}: \mathrm{K}_{115}, \mathrm{~N}_{250}: \mathrm{P}_{165}: \mathrm{K}_{165}$, $\mathrm{N}_{250}: \mathrm{P}_{65}: \mathrm{K}_{65}, \mathrm{~N}_{350}: \mathrm{P}_{115}: \mathrm{K}_{165}, \mathrm{~N}_{350}: \mathrm{P}_{115}: \mathrm{K}_{115}, \mathrm{~N}_{350}$ : $\mathrm{P}_{115}: \mathrm{K}_{165}, \mathrm{~N}_{350}: \mathrm{P}_{165}: \mathrm{K}_{65}, \mathrm{~N}_{350}: \mathrm{P}_{165}: \mathrm{K}_{115}, \mathrm{~N}_{350}: \mathrm{P}_{165}$ : $\mathrm{K}_{165}$. The N, $\mathrm{P}$ and $\mathrm{K}$ were applied through urea, single super phosphate and muriate of potash, respectively as per treatments. Preseasonal sugarcane (CO-94012) was taken as a main test crop in these FYM blocks and after harvest of preseasonal sugarcane crop, the cane and top yield were recorded. Without disturbing the fertility gradient and FYM blocks, after harvest of preseasonal plant cane in February, 2008. The same field of harvested plant preseasonal sugarcane are used for soil test crop response correlation studies for preseasonal ratoon sugarcane to develop the relationship between soil test value and cane yields by conducting experiment on fertility gradient approach (Ramammorthy et al., 1967) with the view to derive fertilizer prescription equation for preseasonal ratoon sugarcane by conjoint use of chemical fertilizers and organic manures for making judicious and balanced fertilizer recommendations for a system as a whole. The treatment of $\mathrm{N}, \mathrm{P}_{2} \mathrm{O}_{5}$ and $\mathrm{K}_{2} \mathrm{O}$ proportions for preseasonal ratoon sugarcane were superimposed on the similar treatment of $\mathrm{N}, \mathrm{P}_{2} \mathrm{O}_{5}$ and $\mathrm{K}_{2} \mathrm{O}$ proportion of preseasonal plant sugarcane. The growth observations such as maximum number of internodes, number of leaves, length of internodes, girth of internodes and height of millable cane were recorded at harvesting 
N. B. Ghube et al. / J. Appl. \& Nat. Sci. 9 (2): 812 - 820 (2017)

Table 3. Effect of fertilization on growth parameter of pre-seasonal sugarcane (ratoon) in $30 \mathrm{t} \mathrm{FYM} \mathrm{ha} \mathrm{F}^{-1}$ block.

\begin{tabular}{|c|c|c|c|c|c|c|}
\hline \multirow[b]{2}{*}{ Tr. No. } & \multirow[b]{2}{*}{ Treatment } & \multicolumn{5}{|c|}{ F2 $\left(30 \mathrm{tha}^{-1}\right)$} \\
\hline & & $\begin{array}{l}\text { Number of } \\
\text { internodes }\end{array}$ & $\begin{array}{c}\text { Number of } \\
\text { Leaves }\end{array}$ & $\begin{array}{l}\text { Length of internodes } \\
\text { (cm) }\end{array}$ & $\begin{array}{l}\text { Girth of inter- } \\
\text { nodes }(\mathrm{cm})\end{array}$ & $\begin{array}{l}\text { Height of milla- } \\
\text { ble cane }(\mathrm{cm})\end{array}$ \\
\hline 1 & $\mathrm{~N}_{0} \mathrm{P}_{115} \mathrm{~K}_{115}$ & 23 & 10 & 12.50 & 11.30 & 335 \\
\hline 2 & $\mathrm{~N}_{150} \mathrm{P}_{65} \mathrm{~K}_{65}$ & 21 & 9 & 13.50 & 11.30 & 345 \\
\hline 3 & $\mathrm{~N}_{150} \mathrm{P}_{65} \mathrm{~K}_{115}$ & 24 & 9 & 13.60 & 11.70 & 337 \\
\hline 4 & $\mathrm{~N}_{150} \mathrm{P}_{155} \mathrm{~K}_{65}$ & 25 & 8 & 13.10 & 12.30 & 340 \\
\hline 5 & $\mathrm{~N}_{150} \mathrm{P}_{115} \mathrm{~K}_{115}$ & 25 & 7 & 14.00 & 12.85 & 360 \\
\hline 6 & $\mathrm{~N}_{250} \mathrm{P}_{0} \mathrm{~K}_{115}$ & 21 & 8 & 13.90 & 12.40 & 360 \\
\hline 7 & $\mathrm{~N}_{250} \mathrm{P}_{65} \mathrm{~K}_{65}$ & 22 & 6 & 14.00 & 11.80 & 355 \\
\hline 8 & $\mathrm{~N}_{250} \mathrm{P}_{65} \mathrm{~K}_{115}$ & 24 & 6 & 13.80 & 12.30 & 363 \\
\hline 9 & $\mathrm{~N}_{250} \mathrm{P}_{115} \mathrm{~K}_{65}$ & 25 & 7 & 14.00 & 12.55 & 368 \\
\hline 10 & $\mathrm{~N}_{250} \mathrm{P}_{115} \mathrm{~K}_{0}$ & 27 & 8 & 14.50 & 12.30 & 365 \\
\hline 11 & $\mathrm{~N}_{250} \mathrm{P}_{115} \mathrm{~K}_{115}$ & 26 & 6 & 14.50 & 11.90 & 355 \\
\hline 12 & $\mathrm{~N}_{250} \mathrm{P}_{115} \mathrm{~K}_{165}$ & 28 & 6 & 15.00 & 12.30 & 340 \\
\hline 13 & $\mathrm{~N}_{250} \mathrm{P}_{165} \mathrm{~K}_{115}$ & 28 & 7 & 15.50 & 12.45 & 360 \\
\hline 14 & $\mathrm{~N}_{250} \mathrm{P}_{165} \mathrm{~K}_{165}$ & 25 & 7 & 15.50 & 12.20 & 335 \\
\hline 15 & $\mathrm{~N}_{350} \mathrm{P}_{65} \mathrm{~K}_{65}$ & 26 & 6 & 15.50 & 11.80 & 342 \\
\hline 16 & $\mathrm{~N}_{350} \mathrm{P}_{115} \mathrm{~K}_{65}$ & 29 & 7 & 15.85 & 12.65 & 357 \\
\hline 17 & $\mathrm{~N}_{350} \mathrm{P}_{115} \mathrm{~K}_{115}$ & 29 & 7 & 16.00 & 12.90 & 335 \\
\hline 18 & $\mathrm{~N}_{350} \mathrm{P}_{115} \mathrm{~K}_{165}$ & 27 & 6 & 16.35 & 13.00 & 365 \\
\hline 19 & $\mathrm{~N}_{350} \mathrm{P}_{165} \mathrm{~K}_{65}$ & 26 & 8 & 16.80 & 13.10 & 370 \\
\hline 20 & $\mathrm{~N}_{350} \mathrm{P}_{165} \mathrm{~K}_{115}$ & 30 & 7 & 16.40 & 12.80 & 385 \\
\hline 21 & $\mathrm{~N}_{350} \mathrm{P}_{165} \mathrm{~K}_{165}$ & 30 & 8 & 16.60 & 13.30 & 390 \\
\hline 22 & $\mathrm{~N}_{0} \mathrm{P}_{0} \mathrm{~K}_{0}$ & 24 & 7 & 11.50 & 11.30 & 325 \\
\hline 23 & $\mathrm{~N}_{0} \mathrm{P}_{0} \mathrm{~K}_{0}$ & 22 & 7 & 10.98 & 10.90 & 310 \\
\hline 24 & $\mathrm{~N}_{0} \mathrm{P}_{0} \mathrm{~K}_{0}$ & 23 & 6 & 12.35 & 10.12 & 345 \\
\hline \multicolumn{2}{|c|}{ Average of treated plots } & 25.42 & 7.21 & 14.41 & 12.15 & 351.75 \\
\hline \multicolumn{2}{|c|}{ Average of control plots } & 23 & 6.66 & 11.61 & 10.77 & 326.66 \\
\hline
\end{tabular}

stage. The biochemical parameters viz. brix, purity (\%) and CCS (\%) were estimated in the laboratory as per the procedure outlined by Spencer and Meade (1964) and for Pol (\%) by Lane and Euton (1993). At the age of 12 months, five stalk samples were collected and the analysis was performed on five stalk sample. The stalks were shredded using a cutter grinder. The shredded material was then mixed thoroughly and juice was extracted. Using lead acetate the juice was clarified and filtered. The polarization reading was taken by using polarization universal and the juice was analysed for quality parameters (Lane and Euton, 1993). Preseasonal sugarcane ratoon (CO-94012) was taken as a main test crop in these FYM blocks and at the time of harvest of preseasonal sugarcane ratoon crop, the cane and top yields were recorded.

\section{RESULTS AND DISCUSSION}

Study site and soil description: The average annual precipitation during experiment period was $520 \mathrm{~mm}$. Out of the total annual rainfall, about 80 per cent rains are received from South-West monsoon (June to September) while rest receives from North-East monsoon. The number of rainy days were varies from 15 45 days in a year. Total rainfall received during the period from February, 2008 to January, 2009 was $670.7 \mathrm{~mm}$ in 23 rainy days. The experimental soil belongs to order Inceptisol and sub group of Vertic Hap- lustepts. The texture of the soil was clayey with low in available $\mathrm{N}\left(178.33 \mathrm{~kg} \mathrm{ha}^{-1}\right)$, medium in available $\mathrm{P}$ $\left(18.78 \mathrm{~kg} \mathrm{ha}^{-1}\right)$ and very high in $\mathrm{K}\left(350.33 \mathrm{~kg} \mathrm{ha}^{-1}\right)$. The soil was slightly alkaline in reaction with calcium carbonate content of 7.90 per cent.

Growth parameters of preseasonal sugarcane ratoon: The effect of NPK combination along with residual effect of FYM 0,15 and $30 \mathrm{t} \mathrm{ha}^{-1}$ on growth parameters of preseasonal sugarcane ratoon in $\mathrm{F}_{0}, \mathrm{~F}_{1}$ and $F_{2}$ FYM blocks at harvest are presented in Table 1, 2 and 3 . The growth parameters varied by graded doses of $\mathrm{N}, \mathrm{P}_{2} \mathrm{O}_{5}$ and $\mathrm{K}_{2} \mathrm{O}$. The addition of $\mathrm{N} @ 350 \mathrm{~kg} \mathrm{ha}^{-1}$ in combination with graded doses of $\mathrm{P}_{2} \mathrm{O}_{5} \& \mathrm{~K}_{2} \mathrm{O}$ were beneficial for improving the morphological characteristics of sugarcane ratoon with residual effect of FYM addition. The morphological growth parameters recorded in residual effect of $F_{1}$ block (15 tha ${ }^{-1}$ FYM) in combination with graded doses of NPK were recorded the higher values than in $\mathrm{F}_{0}$ FYM blocks (Table 1 and 2). It was higher in $\mathrm{N}$ application @ $350 \mathrm{~kg} \mathrm{ha}^{-1}$ along with $\mathrm{P}_{2} \mathrm{O}_{5}$ and $\mathrm{K}_{2} \mathrm{O}$ levels than the 250 and $150 \mathrm{~kg}$ $\mathrm{ha}^{-1} \mathrm{~N}$ application. This might be because of $\mathrm{N}$ application of ratoon sugarcane enhanced the vegetative growth. Similarly, because of residual effect of 15 $\mathrm{t} \mathrm{ha}^{-1} \mathrm{FYM}$ may mineralize the nitrogen, reduce the loss either by leaching or volatization as result nitrogen was more efficiently used by preseasonal ratoon sugarcane and reflected in morphological parameters. Similar, observations were recorded by the Shridevi et al. (2016) found that the application of $100 \%$ recom- 
N. B. Ghube et al. / J. Appl. \& Nat. Sci. 9 (2): 812 - 820 (2017)

Table 4. Effect of fertilization on yield and CCS yield of pre-seasonal sugarcane ratoon in different FYM block.

\begin{tabular}{|c|c|c|c|c|c|c|c|}
\hline \multirow{3}{*}{$\begin{array}{l}\text { Tr. } \\
\text { No. }\end{array}$} & \multirow{3}{*}{ Treatment } & \multicolumn{6}{|c|}{ Cane yield and CCS yield ( $\mathrm{MT} \mathrm{ha}^{-1}$ ) } \\
\hline & & \multicolumn{2}{|c|}{$F_{0}\left(0\right.$ t ha $\left.^{-1}\right)$} & \multicolumn{2}{|c|}{$F_{1}\left(15 \mathrm{tha}^{-1}\right)$} & \multicolumn{2}{|c|}{$F_{2}\left(30\right.$ t ha $\left.^{-1}\right)$} \\
\hline & & Cane & CCS & Cane & CCS & Cane & CCS \\
\hline 1 & $\mathrm{~N}_{0} \mathrm{P}_{115} \mathrm{~K}_{115}$ & 76.41 & 7.82 & 88.72 & 8.50 & 98.56 & 9.58 \\
\hline 2 & $\mathrm{~N}_{150} \mathrm{P}_{65} \mathrm{~K}_{65}$ & 77.20 & 7.80 & 130.11 & 12.86 & 114.12 & 10.82 \\
\hline 3 & $\mathrm{~N}_{150} \mathrm{P}_{65} \mathrm{~K}_{115}$ & 96.54 & 9.76 & 85.49 & 9.43 & 118.45 & 13.46 \\
\hline 4 & $\mathrm{~N}_{150} \mathrm{P}_{115} \mathrm{~K}_{65}$ & 73.62 & 7.72 & 104.36 & 10.89 & 111.45 & 12.00 \\
\hline 5 & $\mathrm{~N}_{150} \mathrm{P}_{115} \mathrm{~K}_{115}$ & 82.26 & 9.53 & 106.23 & 7.55 & 119.58 & 13.59 \\
\hline 6 & $\mathrm{~N}_{250} \mathrm{P}_{0} \mathrm{~K}_{115}$ & 87.90 & 9.65 & 96.66 & 10.07 & 109.56 & 14.10 \\
\hline 7 & $\mathrm{~N}_{250} \mathrm{P}_{65} \mathrm{~K}_{65}$ & 65.67 & 5.66 & 92.26 & 9.23 & 131.25 & 15.02 \\
\hline 8 & $\mathrm{~N}_{250} \mathrm{P}_{65} \mathrm{~K}_{115}$ & 93.66 & 8.15 & 98.58 & 10.03 & 118.90 & 11.55 \\
\hline 9 & $\mathrm{~N}_{250} \mathrm{P}_{115} \mathrm{~K}_{65}$ & 100.65 & 13.22 & 107.24 & 11.28 & 125.34 & 13.06 \\
\hline 10 & $\mathrm{~N}_{250} \mathrm{P}_{115} \mathrm{~K}_{0}$ & 95.54 & 9.41 & 107.89 & 13.12 & 116.54 & 12.47 \\
\hline 11 & $\mathrm{~N}_{250} \mathrm{P}_{115} \mathrm{~K}_{115}$ & 112.25 & 10.26 & 115.25 & 10.13 & 128.56 & 15.54 \\
\hline 12 & $\mathrm{~N}_{250} \mathrm{P}_{115} \mathrm{~K}_{165}$ & 111.25 & 12.04 & 111.35 & 12.17 & 131.25 & 14.26 \\
\hline 13 & $\mathrm{~N}_{250} \mathrm{P}_{165} \mathrm{~K}_{115}$ & 93.66 & 11.74 & 95.56 & 9.01 & 141.25 & 16.30 \\
\hline 14 & $\mathrm{~N}_{250} \mathrm{P}_{165} \mathrm{~K}_{165}$ & 93.25 & 10.64 & 109.25 & 10.69 & 124.25 & 13.20 \\
\hline 15 & $\mathrm{~N}_{350} \mathrm{P}_{65} \mathrm{~K}_{65}$ & 108.88 & 11.83 & 100.37 & 11.46 & 131.25 & 13.74 \\
\hline 16 & $\mathrm{~N}_{350} \mathrm{P}_{115} \mathrm{~K}_{65}$ & 97.36 & 9.62 & 111.45 & 11.57 & 135.22 & 14.86 \\
\hline 17 & $\mathrm{~N}_{350} \mathrm{P}_{115} \mathrm{~K}_{115}$ & 92.36 & 9.99 & 117.58 & 11.69 & 118.25 & 12.14 \\
\hline 18 & $\mathrm{~N}_{350} \mathrm{P}_{115} \mathrm{~K}_{165}$ & 93.25 & 9.63 & 120.22 & 12.15 & 121.22 & 12.49 \\
\hline 19 & $\mathrm{~N}_{350} \mathrm{P}_{165} \mathrm{~K}_{65}$ & 125.22 & 12.59 & 109.25 & 11.61 & 114.45 & 11.30 \\
\hline 20 & $\mathrm{~N}_{350} \mathrm{P}_{165} \mathrm{~K}_{115}$ & 110.15 & 11.25 & 108.65 & 10.98 & 118.59 & 11.93 \\
\hline 21 & $\mathrm{~N}_{350} \mathrm{P}_{165} \mathrm{~K}_{165}$ & 116.52 & 12.16 & 113.25 & 11.69 & 121.22 & 11.38 \\
\hline 22 & $\mathrm{~N}_{0} \mathrm{P}_{0} \mathrm{~K}_{0}$ & 37.48 & 6.24 & 41.70 & 3.99 & 43.18 & 7.62 \\
\hline 23 & $\mathrm{~N}_{0} \mathrm{P}_{0} \mathrm{~K}_{0}$ & 29.25 & 5.77 & 32.81 & 5.36 & 33.32 & 5.64 \\
\hline 24 & $\mathrm{~N}_{0} \mathrm{P}_{0} \mathrm{~K}_{0}$ & 56.41 & 9.16 & 67.85 & 6.82 & 68.28 & 10.74 \\
\hline \multicolumn{2}{|c|}{ Average of treated plots } & 99.12 & 9.65 & 104.33 & 10.10 & 120.32 & 14.13 \\
\hline \multicolumn{2}{|c|}{ Average of control plots } & 41.04 & 7.05 & 47.45 & 5.39 & 48.26 & 8.00 \\
\hline
\end{tabular}

mended dose of fertilizer (RDF) along with FYM @ $25 \mathrm{t} \mathrm{ha}^{-1}$, micronutrients @ $25 \mathrm{~kg}$ each of $\mathrm{ZnSO}_{4}$ and $\mathrm{FeSO}_{4}$ and biofertilzers (Azospirillium and PSB @ 10 $\mathrm{kg} \mathrm{ha}^{-1}$ each) were better for improved growth parameters and yield as well as obtaining higher economical returns from sugarcane cultivation. The morphological attributes of ratoon sugarcane as affected by the residual effect $30 \mathrm{t} \mathrm{ha}^{-1} \mathrm{FYM}$ along with NPK combinations showed the similar trend to that of in $F_{1}\left(15 \mathrm{tha}^{-1}\right.$ residual effect of FYM). However, numerical values of all the morphological attributes were higher than the values observed in $F_{1}$ FYM blocks (Table 2 and 3). The number of internodes were ranged between 21-30 with mean of 25.42, length of internodes 12.50-16.80 $\mathrm{cm}$ with mean of $14.41 \mathrm{~cm}$, girth of internodes 11.30$13.10 \mathrm{~cm}$ with mean of $12.15 \mathrm{~cm}$ and height of millable cane 335-385 with mean of $351.75 \mathrm{~cm}$, respectively. The results revealed that addition of $30 \mathrm{t} \mathrm{ha}^{-1} \mathrm{FYM}$ to plant preseasonal sugarcane and their residual effect on ratoon sugarcane with an application of graded levels of $\mathrm{N}, \mathrm{P}_{2} \mathrm{O}_{5}$ and $\mathrm{K}_{2} \mathrm{O}$ in combination was found superior for morphological attributes of sugarcane ratoon. The results of the study are also supported by Abdul Fatah Soomro (2014) with opinion that enhanced the growth, yield, quality and nutrient uptake of both plant and ratoon sugarcane.

Yield of preseasonal sugarcane ratoon: The cane yield data of preseasonal sugarcane ratoon in Table 4 indicated that an increasing trend with increase in the residual FYM from 0 to 15 and $30 \mathrm{t} \mathrm{FYM} \mathrm{ha}{ }^{-1}$. The cane yield in treated plots as ratoon sugarcane experiment in the $\mathrm{F}_{0}$ blocks was ranged from 65.67 to 125.22 MT $\mathrm{ha}^{-1}$. These results showed that there was an increase in cane yield of preseasonal ratoon sugarcane with increase in $\mathrm{N}, \mathrm{P}_{2} \mathrm{O}_{5}$ and $\mathrm{K}_{2} \mathrm{O}$ levels. The maximum being with $\mathrm{N}_{350} \mathrm{P}_{165} \mathrm{~K}_{65}$ treatment. The average yield of control plot of $\mathrm{F}_{0}$ block was $41.04 \mathrm{MT} \mathrm{ha}^{-1}$. The cane yield of preseasonal ratoon sugarcane in $F_{1}$ block showed similar trend to that of $\mathrm{F}_{0}$ blocks. The residual effect of $15 \mathrm{t} \mathrm{FYM} \mathrm{ha}{ }^{-1}$ along with $\mathrm{N}, \mathrm{P}_{2} \mathrm{O}_{5}$ and $\mathrm{K}_{2} \mathrm{O}$ treatments increased the cane yield and ranging from 85.49 to $130.11 \mathrm{MT} \mathrm{ha}^{-1}$ with average cane yield 104.33 MT ha $\mathrm{a}^{-1}$. The average cane yield in control plot was $47.45 \mathrm{MT} \mathrm{ha}^{-1}$. The highest cane yield of $130.11 \mathrm{t}$ $\mathrm{ha}^{-1}$ was observed in $\mathrm{N}_{150} \mathrm{P}_{65} \mathrm{~K}_{165}$ followed by 120.22 MT ha ${ }^{-1}$ of $\mathrm{N}_{350} \mathrm{P}_{115} \mathrm{~K}_{165}$ treatment. The residual fertility in the $\mathrm{F}_{1}$ strip along with FYM might be used to increase the cane yields. Bokhtiar et al., (2015) reported that the combined application of enriched pressmud or raw pressmud with chemical fertilizers improved the cane yield and the effect was more pronounced at higher fertilizer level (100 \% RDF). The $\mathrm{F}_{2}$ block with $30 \mathrm{tha}^{-1}$ residual FYM the ratoon cane yield was ranged between 98.56-141.25 MT ha ${ }^{-1}$ and mean of control plots was 48.26 MT ha ${ }^{-1}$. There was an increase in yield of control plots in $F_{2}$ blocks than $F_{0}$ and $F_{1}$ blocks. This shows the beneficial effect of residual FYM in increasing the cane yield of preseasonal sug- 
N. B. Ghube et al. / J. Appl. \& Nat. Sci. 9 (2): 812 - 820 (2017)

Table 5. Effect of fertilization on quality parameter of pre-seasonal sugarcane ratoon in without FYM.

\begin{tabular}{|c|c|c|c|c|c|c|}
\hline \multirow{2}{*}{ Tr. No. } & \multirow{2}{*}{ Treatment } & \multicolumn{5}{|c|}{ F0 $\left(0\right.$ t ha $\left.^{-1}\right)$} \\
\hline & & Brix $\left({ }^{0} \mathrm{C}\right)$ & Pol (\%) & Invert sugar (\%) & Purity (\%) & CCS (\%) \\
\hline 1 & $\mathrm{~N}_{0} \mathrm{P}_{115} \mathrm{~K}_{115}$ & 22.80 & 16.21 & 0.40 & 71.09 & 8.82 \\
\hline 2 & $\mathrm{~N}_{150} \mathrm{P}_{65} \mathrm{~K}_{65}$ & 20.80 & 17.06 & 0.50 & 82.01 & 10.11 \\
\hline 3 & $\mathrm{~N}_{150} \mathrm{P}_{65} \mathrm{~K}_{115}$ & 20.80 & 17.06 & 0.51 & 82.01 & 10.11 \\
\hline 4 & $\mathrm{~N}_{150} \mathrm{P}_{115} \mathrm{~K}_{65}$ & 19.60 & 17.13 & 0.54 & 87.39 & 10.49 \\
\hline 5 & $\mathrm{~N}_{150} \mathrm{P}_{115} \mathrm{~K}_{115}$ & 22.40 & 16.27 & 0.50 & 72.63 & 8.98 \\
\hline 6 & $\mathrm{~N}_{250} \mathrm{P}_{0} \mathrm{~K}_{115}$ & 22.80 & 18.59 & 0.47 & 81.53 & 10.98 \\
\hline 7 & $\mathrm{~N}_{250} \mathrm{P}_{65} \mathrm{~K}_{65}$ & 22.30 & 15.56 & 0.46 & 69.77 & 8.62 \\
\hline 8 & $\mathrm{~N}_{250} \mathrm{P}_{65} \mathrm{~K}_{115}$ & 21.80 & 15.80 & 0.59 & 72.47 & 8.71 \\
\hline 9 & $\mathrm{~N}_{250} \mathrm{P}_{115} \mathrm{~K}_{65}$ & 20.80 & 17.54 & 0.47 & 84.32 & 10.55 \\
\hline 10 & $\mathrm{~N}_{250} \mathrm{P}_{115} \mathrm{~K}_{0}$ & 21.80 & 16.51 & 0.46 & 75.73 & 9.35 \\
\hline 11 & $\mathrm{~N}_{250} \mathrm{P}_{115} \mathrm{~K}_{115}$ & 21.80 & 16.75 & 0.53 & 76.83 & 9.57 \\
\hline 12 & $\mathrm{~N}_{250} \mathrm{P}_{115} \mathrm{~K}_{165}$ & 20.00 & 17.61 & 0.49 & 88.05 & 10.82 \\
\hline 13 & $\mathrm{~N}_{250} \mathrm{P}_{165} \mathrm{~K}_{115}$ & 19.80 & 17.34 & 0.48 & 87.57 & 10.63 \\
\hline 14 & $\mathrm{~N}_{250} \mathrm{P}_{165} \mathrm{~K}_{165}$ & 18.80 & 17.93 & 0.46 & 95.37 & 11.42 \\
\hline 15 & $\mathrm{~N}_{350} \mathrm{P}_{65} \mathrm{~K}_{65}$ & 19.80 & 17.61 & 0.58 & 88.93 & 10.87 \\
\hline 16 & $\mathrm{~N}_{350} \mathrm{P}_{115} \mathrm{~K}_{65}$ & 20.80 & 16.82 & 0.51 & 80.86 & 9.89 \\
\hline 17 & $\mathrm{~N}_{350} \mathrm{P}_{115} \mathrm{~K}_{115}$ & 19.80 & 17.61 & 0.53 & 88.93 & 10.82 \\
\hline 18 & $\mathrm{~N}_{350} \mathrm{P}_{155} \mathrm{~K}_{165}$ & 20.80 & 17.30 & 0.59 & 83.17 & 10.33 \\
\hline 19 & $\mathrm{~N}_{350} \mathrm{P}_{165} \mathrm{~K}_{65}$ & 21.00 & 17.06 & 0.69 & 81.23 & 10.06 \\
\hline 20 & $\mathrm{~N}_{350} \mathrm{P}_{165} \mathrm{~K}_{115}$ & 21.80 & 17.47 & 0.71 & 80.13 & 10.22 \\
\hline 21 & $\mathrm{~N}_{350} \mathrm{P}_{165} \mathrm{~K}_{165}$ & 21.80 & 17.71 & 0.79 & 81.23 & 10.44 \\
\hline 22 & $\mathrm{~N}_{0} \mathrm{P}_{0} \mathrm{~K}_{0}$ & 22.80 & 16.68 & 0.47 & 73.15 & 9.26 \\
\hline 23 & $\mathrm{~N}_{0} \mathrm{P}_{0} \mathrm{~K}_{0}$ & 22.00 & 16.99 & 0.45 & 77.22 & 9.74 \\
\hline 24 & $\mathrm{~N}_{0} \mathrm{P}_{0} \mathrm{~K}_{0}$ & 20.60 & 17.54 & 0.43 & 85.14 & 10.60 \\
\hline \multicolumn{2}{|c|}{ Average of treated plots } & 21.15 & 17.09 & 0.53 & 81.12 & 10.06 \\
\hline \multicolumn{2}{|c|}{ Average of control plots } & 21.80 & 17.07 & 0.45 & 78.50 & 9.86 \\
\hline
\end{tabular}

Table 6. Effect of fertilization on quality parameter of pre-seasonal sugarcane (ratoon) in $15 \mathrm{t} \mathrm{FYM} \mathrm{ha}{ }^{-1}$.

\begin{tabular}{|c|c|c|c|c|c|c|}
\hline \multirow{2}{*}{$\begin{array}{l}\text { Tr. } \\
\text { No. }\end{array}$} & \multirow{2}{*}{ Treatment } & \multicolumn{5}{|c|}{ F1 $\left(15 \mathrm{t} \mathrm{ha}^{-1}\right)$} \\
\hline & & Brix $\left({ }^{0} \mathrm{C}\right)$ & Pol (\%) & Invert sugar (\%) & Purity (\%) & $\operatorname{CCS}(\%)$ \\
\hline 1 & $\mathrm{~N}_{0} \mathrm{P}_{115} \mathrm{~K}_{115}$ & 22.80 & 17.88 & 0.41 & 78.42 & 10.34 \\
\hline 2 & $\mathrm{~N}_{150} \mathrm{P}_{65} \mathrm{~K}_{65}$ & 20.80 & 16.82 & 0.52 & 80.86 & 9.89 \\
\hline 3 & $\mathrm{~N}_{150} \mathrm{P}_{65} \mathrm{~K}_{115}$ & 20.60 & 18.02 & 0.53 & 87.47 & 11.04 \\
\hline 4 & $\mathrm{~N}_{150} \mathrm{P}_{155} \mathrm{~K}_{65}$ & 21.80 & 17.71 & 0.55 & 81.23 & 10.44 \\
\hline 5 & $\mathrm{~N}_{150} \mathrm{P}_{115} \mathrm{~K}_{115}$ & 20.80 & 16.82 & 0.52 & 80.86 & 9.89 \\
\hline 6 & $\mathrm{~N}_{250} \mathrm{P}_{0} \mathrm{~K}_{115}$ & 21.80 & 17.47 & 0.48 & 80.13 & 10.22 \\
\hline 7 & $\mathrm{~N}_{250} \mathrm{P}_{65} \mathrm{~K}_{65}$ & 21.80 & 17.23 & 0.49 & 79.03 & 10.01 \\
\hline 8 & $\mathrm{~N}_{250} \mathrm{P}_{65} \mathrm{~K}_{115}$ & 20.60 & 17.30 & 0.58 & 83.98 & 10.32 \\
\hline 9 & $\mathrm{~N}_{250} \mathrm{P}_{115} \mathrm{~K}_{65}$ & 21.80 & 16.99 & 0.47 & 77.93 & 9.79 \\
\hline 10 & $\mathrm{~N}_{250} \mathrm{P}_{115} \mathrm{~K}_{0}$ & 20.60 & 18.26 & 0.47 & 83.76 & 11.26 \\
\hline 11 & $\mathrm{~N}_{250} \mathrm{P}_{115} \mathrm{~K}_{115}$ & 22.00 & 17.95 & 0.53 & 81.59 & 10.61 \\
\hline 12 & $\mathrm{~N}_{250} \mathrm{P}_{115} \mathrm{~K}_{165}$ & 20.40 & 17.86 & 0.49 & 87.54 & 10.94 \\
\hline 13 & $\mathrm{~N}_{250} \mathrm{P}_{165} \mathrm{~K}_{115}$ & 22.80 & 16.88 & 0.50 & 74.03 & 9.43 \\
\hline 14 & $\mathrm{~N}_{250} \mathrm{P}_{165} \mathrm{~K}_{165}$ & 21.80 & 16.99 & 0.48 & 77.93 & 9.79 \\
\hline 15 & $\mathrm{~N}_{350} \mathrm{P}_{65} \mathrm{~K}_{65}$ & 18.80 & 17.93 & 0.55 & 95.37 & 11.42 \\
\hline 16 & $\mathrm{~N}_{350} \mathrm{P}_{115} \mathrm{~K}_{65}$ & 22.00 & 17.71 & 0.53 & 80.50 & 10.39 \\
\hline 17 & $\mathrm{~N}_{350} \mathrm{P}_{115} \mathrm{~K}_{115}$ & 20.80 & 16.82 & 0.59 & 80.86 & 9.89 \\
\hline 18 & $\mathrm{~N}_{350} \mathrm{P}_{115} \mathrm{~K}_{165}$ & 20.80 & 17.06 & 0.66 & 82.01 & 10.11 \\
\hline 19 & $\mathrm{~N}_{350} \mathrm{P}_{165} \mathrm{~K}_{65}$ & 19.80 & 17.34 & 0.70 & 87.57 & 10.63 \\
\hline 20 & $\mathrm{~N}_{350} \mathrm{P}_{165} \mathrm{~K}_{115}$ & 20.80 & 17.06 & 0.73 & 82.01 & 10.11 \\
\hline 21 & $\mathrm{~N}_{350} \mathrm{P}_{165} \mathrm{~K}_{165}$ & 20.80 & 17.30 & 0.55 & 83.17 & 10.33 \\
\hline 22 & $\mathrm{~N}_{0} \mathrm{P}_{0} \mathrm{~K}_{0}$ & 18.80 & 17.93 & 0.45 & 95.37 & 11.42 \\
\hline 23 & $\mathrm{~N}_{0} \mathrm{P}_{0} \mathrm{~K}_{0}$ & 19.80 & 18.34 & 0.46 & 92.62 & 11.54 \\
\hline 24 & $\mathrm{~N}_{0} \mathrm{P}_{0} \mathrm{~K}_{0}$ & 20.80 & 18.26 & 0.49 & 87.78 & 11.20 \\
\hline \multicolumn{2}{|c|}{ Average of treated plots } & 20.98 & 17.50 & 0.53 & 83.42 & 10.46 \\
\hline \multicolumn{2}{|c|}{ Average of control plots } & 19.80 & 18.17 & 0.46 & 91.92 & 11.38 \\
\hline
\end{tabular}


N. B. Ghube et al. / J. Appl. \& Nat. Sci. 9 (2): 812 - 820 (2017)

Table 7. Effect of fertilization on quality parameter of pre-seasonal sugarcane (ratoon) in $30 \mathrm{t} \mathrm{FYM} \mathrm{ha}{ }^{-1}$

\begin{tabular}{|c|c|c|c|c|c|c|}
\hline \multirow{2}{*}{$\begin{array}{l}\text { Tr. } \\
\text { No. }\end{array}$} & \multirow{2}{*}{ Treatment } & \multicolumn{5}{|c|}{ F2 $\left(30 \mathrm{t} \mathrm{ha}^{-1}\right)$} \\
\hline & & Brix $\left({ }^{0} \mathrm{C}\right)$ & Pol (\%) & Invert sugar (\%) & Purity (\%) & CCS (\%) \\
\hline 1 & $\mathrm{~N}_{0} \mathrm{P}_{115} \mathrm{~K}_{115}$ & 22.88 & 17.23 & 0.52 & 75.30 & 9.73 \\
\hline 2 & $\mathrm{~N}_{150} \mathrm{P}_{65} \mathrm{~K}_{65}$ & 18.80 & 15.81 & 0.48 & 84.09 & 9.49 \\
\hline 3 & $\mathrm{~N}_{150} \mathrm{P}_{65} \mathrm{~K}_{115}$ & 19.00 & 17.93 & 0.55 & 94.36 & 11.37 \\
\hline 4 & $\mathrm{~N}_{150} \mathrm{P}_{115} \mathrm{~K}_{65}$ & 20.80 & 17.78 & 0.53 & 85.48 & 10.77 \\
\hline 5 & $\mathrm{~N}_{150} \mathrm{P}_{115} \mathrm{~K}_{115}$ & 19.00 & 17.93 & 0.50 & 94.36 & 11.37 \\
\hline 6 & $\mathrm{~N}_{250} \mathrm{P}_{0} \mathrm{~K}_{115}$ & 18.80 & 18.41 & 0.55 & 97.92 & 11.86 \\
\hline 7 & $\mathrm{~N}_{250} \mathrm{P}_{65} \mathrm{~K}_{65}$ & 18.70 & 17.93 & 0.60 & 95.88 & 11.45 \\
\hline 8 & $\mathrm{~N}_{250} \mathrm{P}_{65} \mathrm{~K}_{115}$ & 20.80 & 17.54 & 0.53 & 84.32 & 10.55 \\
\hline 9 & $\mathrm{~N}_{250} \mathrm{P}_{115} \mathrm{~K}_{65}$ & 18.80 & 18.17 & 0.50 & 96.64 & 11.64 \\
\hline 10 & $\mathrm{~N}_{250} \mathrm{P}_{115} \mathrm{~K}_{0}$ & 17.80 & 17.79 & 0.49 & 99.94 & 11.56 \\
\hline 11 & $\mathrm{~N}_{250} \mathrm{P}_{115} \mathrm{~K}_{115}$ & 18.80 & 18.66 & 0.55 & 99.25 & 12.09 \\
\hline 12 & $\mathrm{~N}_{250} \mathrm{P}_{115} \mathrm{~K}_{165}$ & 19.20 & 17.44 & 0.51 & 90.83 & 10.87 \\
\hline 13 & $\mathrm{~N}_{250} \mathrm{P}_{165} \mathrm{~K}_{115}$ & 18.60 & 18.00 & 0.55 & 96.77 & 11.54 \\
\hline 14 & $\mathrm{~N}_{250} \mathrm{P}_{165} \mathrm{~K}_{165}$ & 19.80 & 17.34 & 0.55 & 87.57 & 10.63 \\
\hline 15 & $\mathrm{~N}_{350} \mathrm{P}_{65} \mathrm{~K}_{65}$ & 20.40 & 17.34 & 0.53 & 85.00 & 10.47 \\
\hline 16 & $\mathrm{~N}_{350} \mathrm{P}_{115} \mathrm{~K}_{65}$ & 20.80 & 18.02 & 0.51 & 86.63 & 10.99 \\
\hline 17 & $\mathrm{~N}_{350} \mathrm{P}_{115} \mathrm{~K}_{115}$ & 20.80 & 17.30 & 0.53 & 83.17 & 10.33 \\
\hline 18 & $\mathrm{~N}_{350} \mathrm{P}_{115} \mathrm{~K}_{165}$ & 20.30 & 17.13 & 0.67 & 84.38 & 10.31 \\
\hline 19 & $\mathrm{~N}_{350} \mathrm{P}_{165} \mathrm{~K}_{65}$ & 20.30 & 17.23 & 0.75 & 77.26 & 9.88 \\
\hline 20 & $\mathrm{~N}_{350} \mathrm{P}_{165} \mathrm{~K}_{115}$ & 21.00 & 17.06 & 0.58 & 81.23 & 10.06 \\
\hline 21 & $\mathrm{~N}_{350} \mathrm{P}_{165} \mathrm{~K}_{165}$ & 21.80 & 16.55 & 0.59 & 75.91 & 9.39 \\
\hline 22 & $\mathrm{~N}_{0} \mathrm{P}_{0} \mathrm{~K}_{0}$ & 19.00 & 17.93 & 0.46 & 94.36 & 11.37 \\
\hline 23 & $\mathrm{~N}_{0} \mathrm{P}_{0} \mathrm{~K}_{0}$ & 19.80 & 17.34 & 0.48 & 87.57 & 10.63 \\
\hline 24 & $\mathrm{~N}_{0} \mathrm{P}_{0} \mathrm{~K}_{0}$ & 20.80 & 16.82 & 0.50 & 80.86 & 9.89 \\
\hline Ave & of treated plots & 19.87 & 17.53 & 0.54 & 88.30 & 10.76 \\
\hline Ave & of control plots & 19.86 & 17.36 & 0.48 & 87.59 & 10.63 \\
\hline
\end{tabular}

arcane ratoon. The average cane yield of preseasonal ratoon sugarcane in $\mathrm{F}_{0}, \mathrm{~F}_{1}$ and $\mathrm{F}_{2}$ blocks were 99.12, 104.33 and 120.32 $\mathrm{MT} \mathrm{ha}{ }^{-1}$, respectively. The increased cane yield revealed that additional effect of residual FYM in combination with $\mathrm{N}, \mathrm{P}_{2} \mathrm{O}_{5}$ and $\mathrm{K}_{2} \mathrm{O}$ treatments. The cane yield in treated plots of $\mathrm{F}_{1} \mathrm{FYM}$ block was increased by 5.25 per cent over $\mathrm{F}_{0}$ block and by 21.38 per cent in $F_{2}$ blocks over $F_{0}$ blocks. The cane yield of control plots of $F_{1}$ and $F_{2}$ blocks was increased by 15.61 and 17.59 per cent over the cane yield of control plots of the $\mathrm{F}_{0}$ blocks. This has indicated that addition of FYM alone and in combination with $\mathrm{N}, \mathrm{P}_{2} \mathrm{O}_{5}$ and $\mathrm{K}_{2} \mathrm{O}$ fertilizers helped in increasing the preseasonal sugarcane ratoon. The higher doses of $\mathrm{P}_{2} \mathrm{O}_{5}$ and $\mathrm{K}_{2} \mathrm{O}$ were enhanced the CCS yield. This might be associated with the $\mathrm{P}$ may enhanced the activity of sucrose synthetase, which was responsible for sugar synthesis in sugarcane. The CCS yield observed in $\mathrm{F}_{1}$ (residual effect of $15 \mathrm{t} \mathrm{ha}^{-1} \mathrm{FYM}$ ) were higher than the $\mathrm{F}_{0}$ FYM block. The invert sugars content of cane juice showed similar trend to that in $F_{1}$ FYM block. The addition of FYM to plant preseasonal sugarcane ratoon @ 15 and $30 \mathrm{t} \mathrm{ha}^{-1}$ and their residual effect on ratoon preseasonal cane in combination with varying levels of $\mathrm{N}, \mathrm{P}_{2} \mathrm{O}_{5}$ and $\mathrm{K}_{2} \mathrm{O}$ are more beneficial for improving the juice quality and commercial cane sugar yield. This might be associated with enhanced availability of plant nutrients, supply of micronutrients through FYM provides balanced nutrition to sugarcane. Similarly, improvement in biological and physical condition of soil. The findings of Abdul Fatah Soomro (2014) studied the effect of inorganic and organic nutrient sources and rates for sugarcane production and reported that the integrated nutrient management recorded $25 \%$ saving in inorganic NPK fertilizers due to application of FYM and or press mud applied at $20 \mathrm{tha}^{-1}$ and enhanced the growth, yield, quality and nutrient uptake of both plant and ratoon sugarcane. Umesh et al. (2013) reported that the number of tillers, millable cane count, sugarcane and sugar yield were significantly increased at higher level of $\mathrm{N}$ when applied with organic manure where as the effect of biogas slurry was found more pronounced. Haque et al.,(2011) reported that the combined use of either pressmud or farmyard manure (a) $10 \mathrm{tha}^{-1}$ with $2 / 3^{\text {rd }}$ recommended dose of inorganic fertilizer may be suggested for higher sugarcane yield and maintenance of soil fertility in high Ganges River Floodplain (AEZ11).

Juice quality of preseasonal sugarcane ratoon: The juice quality of preseasonal ratoon sugarcane as influenced by the residual effect of FYM and NPK combinations are depicted in Table 5,6 and 7. The brix, Pol and purity per cent of preseasonal sugarcane ratoon at harvest were not considerably influenced by the NPK treatment combination with the residual effect in $\mathrm{F}_{0}$ blocks (Table 5). However, per cent commercial cane sugar (CCS) content was higher in higher doses of NPK application. The higher doses of P and $\mathrm{K}$ were enhanced the CCS per cent. This might be associated with the $\mathrm{P}$ may enhanced the activity of 
sucrose synthetase, which was responsible for sugar synthesis in sugarcane. The $\mathrm{K}$ was mostly useful in translocation of sugars from source to sink. Similarly, $\mathrm{K}$ enhanced the activity of many enzymes in plant system. The juice quality of preseasonal ratoon sugarcane in respect to brix, pol, purity, invert sugars and CCS per cent was affected by residual effect of FYM $\left(15 \mathrm{t} \mathrm{ha}^{-1}\right)$. The Pol per cent of preseasonal ratoon sugarcane was ranged between 16.82-18.26 and purity per cent 78.42-95.37 with an average value of 17.50 and 83.42 (Table 6). The commercial cane sugar content was not considerably affected by residual effect of FYM and treatment combinations of NPK. However, commercial cane sugar yield was higher in high doses of $\mathrm{N}, \mathrm{P}_{2} \mathrm{O}_{5}$ and $\mathrm{K}_{2} \mathrm{O}$ applied to the preseasonal ratoon sugarcane. The Pol, CCS per cent and CCS yield observed in $F_{1}$ (residual effect of $15 \mathrm{tha}^{-1}$ FYM) were higher than the $\mathrm{F}_{0}$ FYM block. The invert sugars content of cane juice showed similar trend to that in $F_{1}$ FYM block. The juice quality of preseasonal sugarcane ratoon in residual effect of $30 \mathrm{t} \mathrm{ha}^{-1}$ FYM block $\left(F_{2}\right)$ was showed the similar trend to that of $F_{0}$ and $F_{1}$ blocks. However, numerically pol, purity and CCS per cent were higher than $\mathrm{F}_{0}$ and $\mathrm{F}_{2}$ FYM blocks. The pol per cent in $\mathrm{F}_{2}$ blocks was ranged from 15.81 to 18.41 per cent with mean of 17.53 per cent and CCS per cent from 9.39 to 12.09 per cent with mean of 10.76 per cent (Table 7). The results indicated that the residual effect of $30 \mathrm{t} \mathrm{ha}^{-1}$ FYM with different NPK combinations were more beneficial for improving juice quality. Minimum quality parameters were recorded in RDF alone treatments, might be organic manures are responsible for utilization of assimilated $\mathrm{N}$ in cane and conversion of reducing sugars to recoverable sugars. Application of 100 per cent RDF through inorganic fertilizers alone reduced the quality of juice in terms of brix, sucrose and purity per cent compared with the control, while combination of both organics and inorganic fertilizers improved these parameters over 100 per cent NPK. Ramalakshmi et al. (2011) reported that the better juice quality was observed in manure treated plots than RDF alone. Maximum juice sucrose (19.75 $\%)$ and \% CCS (13.72) was observed in FYM + RDF of plant crop. FYM + RDF registered higher cane yield and sugar yield than application of entire ' $\mathrm{N}$ ' through RDF alone but it was found at par with vermicompost + RDF. The study showed that integrated use of organic manures and inorganic fertilizers produced higher and sustainable cane yields and maintained the soil fertility. The invert sugars content of preseasonal sugarcane ratoon was considerably higher in $\mathrm{N}$ application@ $350 \mathrm{~kg} \mathrm{ha}^{-1}$ and lower in $150 \mathrm{~kg} \mathrm{ha}$ 1 with varying levels of $P$ and $K$. The higher invert sugars content might be because of $\mathrm{N}$ enhanced the activity of invertase enzyme at maturity stage of preseasonal sugarcane ratoon. The invertase enzyme hydrolyse the sucrose into simple sugars viz., glucose and fructose.

\section{Conclusion}

The juice quality pararameters average of pol (17.53 per cent), commercial cane sugar (10.76 per cent), commercial cane sugar yield (14.13 $\mathrm{MT} \mathrm{ha}^{-1}$ ) and cane yield (120.32 $\left.\mathrm{MT} \mathrm{ha}^{-1}\right)$ of preseasonal ratoon sugarcane were higher in residual effect of $30 \mathrm{t} \mathrm{FYM} \mathrm{ha}^{-1}$ as compare to other treatments. The results indicated that the residual effect of $30 \mathrm{t} \mathrm{ha}^{-1}$ FYM with different NPK inorganic combinations were more beneficial for improving juice quality and commercial cane sugar yield parameters of preseasonal sugarcane ratoon and also conserve agro-ecosystem for sustainable crop production

\section{REFERENCES}

Abdul Fatah Soomro. (2014). Integrated effect of organic and inorganic fertilizers on sugarcane crop.1-176

Anonymous. (2016). Government of India, Crops Division,Crops Unit -4, Ready reckoner, Ministry of Agriculture and Farmers Welfare, Department of Agriculture, Cooperation and Farmers Welfare, Room No. 439, Krishi Bhawan, New Delhi, November-2016.

Bokhtiar, S., Roksana, M.S. and Moslehuddin, A.Z.M. (2015). Soil fertility and productivity of sugarcane influenced by enriched pressmud compost with chemical fertilizers. SAARC Journal of Agriculture,13(2): 183-197

Bokhtiar, S. M., Paul, G. C., Rashid, M. A. and Rahman, A. B. M. (2001). Effect of press mud and oganic nitrogen on soil fertility and yield of sugarcane grown in high Ganges river flood plain soils of Bangladesh. Indian Sugar, L1:235-240

Eid, M. M., Salah, F. A. and Mohamed, O. A. (2016). Mean performance and ratooning ability of sugarcane promising genotypes at early clonal selection. AmericanEurasian Journal of Agriculture and Environment Science, 16 (1): 20-27

Haque, M. A., Paul, G. C., Bhokhitar, S. M., Hosssain, G. M. A., Alam, K.M. and Isalm, M.S. (2011). Combined application of organic and inorganic fertilizer for sustainable sugarcane production. Banagladesh journal of sugarcane, 32: 44-48

Lane, J. H. and Eynon, L. (1923). Determination of sugars by Fehling solution with methyl blue as indicator. Journal of Society Chemistry Industrial transformer, 32-36

Ramalakshmi, Ch. S., Sreelatha, T., Usha Rani, T., Rao S. R. K. and Naidu, N. V. (2011). Effect of organic manures on soil fertility and productivity of sugarcane in North coastal zone of Andhra Pradesh. Indian Journal Agricultural Research, 45 (4): 307 - 313

Ramammorthy, B., Narsimhan, R. L. and Dinesh, R. S. (1967). Fertilizer application for specific yield targets of Sonora-64. Indian Farming, 27(4): 43-44

Sakarvadia, H. L., Polara, K. B., Davaria, R. L., Parmar, K. B. and Babariya, N. B. (2012). Soil test based fertilizer recommendation for targeted yields of garlic crop. $A n$ Asian Journal of Soil Science, 7(2):378-382

Shridevi, B. A., Chandrashekar, C. P. and Patil, S. B. (2016). Performance of sugarcane genotypes under organic, 
inorganic and integrated nutrient management systems. Imperial Journal of Interdisciplinary Research, 2(9): 970-979

Spencer, E. F. and Meade, G. P. (1964). Cane sugar hand book $9^{\text {th }}$ Edn. John Willey and Sons INC, New York.

Umesh, U. N., Kumar, V., Alam, M., Sinha, S. K. and Verma, K. (2013). Integrated effect of organic and inorgan- ic fertilizers on yield, quality parameter and nutrient availability of sugarcane in calcareous soil. Sugar Tech, 15: 365-369. doi:10.1007/s12355-013-0213-1

Vajantha, B., Subbarao, M., Nagamadhuri, K.V., Hemanth Kumar, M. and Sarala, N. V. (2014). STCR approach for optimizing yield, quality and economics in Sugarcane. Current Biotica, 8(3): 309-312 